\title{
Music, Dance and the Sama-Bajau 'Diaspora': Understanding Aspects of Links among Communities through Ethnochoreomusicological Perspectives
}

\author{
Matthew C. Maglana Santamaria \\ University of the Philippines Diliman, Philippines
}

\begin{abstract}
Rituals in establishing the cultural as well as links among Sama-Bajau communities across Nusantara or the region that we know as maritime Southeast Asia. Ritual, however, cannot be fully understood unless it is broken into component parts of tangible (material) and intangible (non-material) properties. In this paper, I argue that an ethnochoreomusicological approach, particularly through the examination of specific music pieces and dance forms or styles, can help scholars understand how the seemingly disparate and widely-spread SamaBajau communities in Nusantara are related to each other. Three cases are presented revolving around ritual, music, and dance. The first case is about the magpai-bahau or ritual of the new rice which is shared by

Received:

December 12, 2018

Revised:

December 24, 2018

Accepted:

January 22, 2019

Corresponding Author:

constanciomat@yahoo.com most Sama-Bajau communities in the Sulu-Sulawesi region. Rice from one community is passed on to another, constituting a virtual chain link that reaffirms the bonds between two groups of people. Corollary to this shared ritual practice is the shared repertoire of music(s) and dance(s). The second case concerns the musical model of Titik Tabawan, a kulintangan (aka tagunggo'an) graduated bossed-gong ensemble music piece composed of a distinct combination of melodic and rhythmic patterns that is observed as a 'universally-shared' intangible property in the central region of Nusantara. Although known by different names across communities, this music piece, which is used for accompanying secular forms belonging to the Sama-Bajau igal or pansak (aka pamansak) dance traditions, retains its distinct qualities of rhythmic patterns and remains discernible as a musical model to both practitioners and scholars alike. Finally, the third case illustrates how variants of Igal Tarirai, a percussive dance using bamboo clappers called bola'-bola,' may be used to glean relative distance or proximity in terms of dance performance practice.
\end{abstract}

Keywords: Nusantara (Maritime Southeast Asia); Sama-Bajau Identity(ies); 'Diaspora'; Links; Ethnochoreomusicology.

\section{Introduction}

As instruments of national, regional and global imagination, maps are very useful instruments that reduce to scale the sizes of continents, islands, oceans, lakes and other geological features of the earth. More importantly in a political sense, they depict usually through some color-coding scheme, bold and dotted lines the territorial domains of nation-states; and, in some specialized versions, they indicate ranking of nationstate in terms of income, population size, and other demographic features, which include, among others, the distribution of ethno-linguistic communities across space. In the case of the population distribution of the Sama-Bajau, maps however often fail to depict more important truths or salient features of the people's relationship to their environment. The Sama-Bajau communities are often represented by random dots or spots strewn across a wide area of maritime Southeast Asia, seemingly isolated in their sparseness and, in terms of visual semiotics, insignificant in scale and lacking of historical and political gravitas. In contemporary times, this may very well be a most truthful representation of the Sama-Bajau, since the emergence of the nation-state brought about by colonial (mis)adventures in the region has relegated this group of people literally and figuratively to the problematic margins of national life with their cultural habitat partitioned off and freedom to roam the inner seas curtailed by the oppressive concept of the border. Conventional maps affirm this oppression which limits the Sama-Bajau to small spaces within imaginary borders. These kinds of maps fail the Sama-Bajau for their ontologies assume a fixed domicile located on dry land, unable or unwilling to see the inner seas of Nusantara as spaces mobile living and as veritable meadows and forests from which the sea-oriented people source their sustenance and craft their identity.

If we were to correct conventional maps that include Sama-Bajau dispersions, the dots and spots ought to be enlarged in order to cover domains of the sea which particular Sama-Bajau communities regularly 
traverse following the seasonal winds, currents, and monsoon rains, thus marking their living spaces as they pursue the migratory bounty of fish; visit their traditional moorages that offer them tranquil shelter from the winds and currents of the open sea; and, renew their ties with land-oriented cultures from which they have developed symbiotic relations in trade and cultural encounter. In our corrected map, the Sama-Bajau will be visually powerful. Their habitats will no longer be limited to small coastal communities. Instead, we shall see that their domains consist of island and maritime spheres of habitation and livelihood. These sphere encompass entire sea basins, strategic straits and island corridors. We now realize the Sama-Bajau mobile habitation and cyclical pursuit of livelihood make possible the linking function of the sea and, in many ways, the unfolding of the openness and cosmopolitanism of the maritime mind.

A close examination of Sama-Bajau culture will show that their physically distant and decidedly heterogeneous communities are culturally and sanguineally connected to each other through a chain-link of spheres that represent their habitational and livelihood domains. Like a skeletal network, these spheres make up the interconnected world of the Sama-Bajau. Although no single Sama-Bajau individual ever visits all of the Sama-Bajau communities in maritime Southeast Asia, this individual is nevertheless able to connect to this network through collective memory, sanguineal or affinal relations, and a general awareness of a shared origin either through myth, legend or oral history. Lineages and origins are remembered, and the location of sacred grave sites of ancestors are known, even though one has no opportunity or capacity to visit them in a lifetime. As seen in lineages and grave-markers, Sama-Bajau links may be validated and appreciated through studies of immaterial (intangible) and material (tangible) culture. Shared cultural properties indicate the closeness or proximity of cultural and sanguineal links. The presence or absence of property help mark what we have earlier termed as spheres of habitation and livelihood. In between groups, the presence of shared property can either indicated common origin (saguineal ties) or cultural encounter enlivened by cultural borrowing. In this study, intangible cultural property is examined as an indicator of such links. Three cases are presented based on an interrogation of: a) Pag-omboh Magpai-Bahau (the ritual of offering to the ancestors the newly harvested rice); b) Titik Tabawan (the musical 'mode' of Tabawan); and, c) Igal Tarirai (the percussive dance of the Sitangkai Island Domain).

\section{Pag-omboh Magpai Bahau: The Ritual of the Newly-Harvested Rice}

Bruno Bottignolo (1995) decribes the Pag-omboh Magpai-Bahau (aka Magpai-Bahau) as "the grandest feast" of the Sama Dilaut (aka Bajau Laut or sea-dwelling Sama people). He explains the importance of the ritual as follows:

"The Umboh Pai Baha-o has a distinctive meaning specified by its seasonal context. It can be celebrated only during the span of two or three months starting around the beginning of September when the new rice is harvested. Against this agricultural background, the rite takes on the meaning of thanksgiving and offering. The offering of the first fruits of the rice harvest is the symbolic offering of the entire harvest. And by offering their harvest, the Badjaos offer themselves. The small basket of rice becomes a pledge and a reminder, ultimately of their dependence on Umboh who guarantees their sustenance and their wellbeing (pp. 85-86).”

The importance given to rice by a non-agricultural and sea-oriented people shows the salience of cultural encounter in shaping beliefs and values. It is believed that rice must first be offered to the ancestors before partaking of it. Doing so without the ritual supposedly invites disaster or illness. Among the Sama Dilaut (aka Sama Sitangkai) of Sitangkai, Tawi-Tawi Province, Philippines and the Sama Dilaut of Semporna, Sabah State, Malaysia, the ritual is observed jointly through symbolic transfer. In this practice, the ritual is first conducted in Sitangkai by the Kalamat or Head Igal Djin (dance spirit-bearer). Afterwards, a portion of the rice is brought across the Philippine-Malaysian border to Bangau-Bangau, Semporna where another Kalamat leads the ritual for the community. This practice of ritual in succession indicates the sanguineal link between Sitangkai and Semporna, with Sitangkai as the primary site. Indeed, Sitangkai, Semporna and Sibutu Islands along with the shallows and reefs of Tumindao and the seas in between constitute a cultural space for the Sama Dilaut. As such it may be called the Sitangkai Island Domain or the Sama Sitangkai Cultural Sphere.

The ritual is also found among the Sama Kubang (aka Sama Sikubang) who are said to have first settled in Omadal Island, then spreading to Bum Bum and Larapan Islands, and then populating the interior of interior of Semporna, Sabah, Malaysia (Md. Nor \& Hussin, 2011). The material culture of the Sama 
Kubang appears to indicate some affinity to the Sama Sitangkai. This can best be seen in the intricately ornamented lepa-lepa house-boats, tepo-tepo colorful handwoven mats made of pandanus leaves, as well as in the implements used in rituals. The sacred repertoire of music and dance of the Sama Kubang is almost identical to that of the Sama Sitangkai. This intangible cultural properties found in both Sama Sitangkai and Sama Kubang are most important in the role they play in trance-dancing which allows djin mediums to communicate with the spirit world. Given this commonality in tangible and intangible properties, it may be surmised that the Sama Kubang emerged as a separate ethnic group from the Sama Sitangkai when they adopted agriculture and started to live on land. Given this strong sense of identification, the Sama Kubang Domain may be treated as an overlapping cultural domain with the Sama Sitangkai, with the more obvious overlap happening in the islands of Omadal, Bum Bum and Larapan, separating and fanning out towards the interior of Semporna.

The Magpai-Bahau ritual may also be seen among the Sama Tabawan (Sama Ubian or Obian) of Tabawan Island found in the northeast of Tawi-Tawi Province, Philippines. Among the Yakan, a Sinamaspeaking people who used to be called by the label Sama Yakan, a similar ritual called Megsulang offers bundles of harvested robust bundles of ripened rice grain to the spirit ancestors. It now appears that the rice ritual is a universal practice observable among Sama-Bajau groups found in that chain of coastal and island communities bridging the greater islands of Mindanao and Borneo. If found among Sama-Bajau groups in East Kalimantan, Indonesian Borneo and Sulawesi, comparative studies of ritual practice may shed light on how intangible properties come to be shared or spit off into variant practices. For now, the two other Sama cultural spheres may be temporarily identified; the Tabawan Island Domain, composed of Tabawan Island, South Ubian and North Ubian; and the Yakan Domain in Basilan Island. This spheres or domains may later be linked by intermediate cases which have yet to be studied. The Sama Bangingi of Tungkil Island (now, Bangingi Island) and the Sama Siasi of Siasi Island may yield other variants of the Magpai-Bahau ritual that may be similar to that of the Yakan the Sama Tabawan. The apparent universal practice of this ritual offering to ancestral spirits imply a common origin. A earlier proto Sama-Bajau may have originated the practice which then resulted in variants as individual Sama-Bajau sub-groups emerged and developed distinct identities.

\section{Titik Tabawan: A Musical "Mode” with Many Names}

Titik Tabawan is a specific musical piece played on the kulintangan ensemble (aka tagunggo'an ensemble) composed of the kulintangan graduated bossed-gong, two or three large hanging gongs (a large gong called the agung, a thick-rimmed, small gong called the pulakan, and a narrow-rimmed large gong called the bua), a percussive instrument most likely adopted from the Spanish military drum called the tambul, and a solembat which plays supplementary rhythmic pattern or ostinato at the highest-pitched gong on the kulintangan set. The piece has a decidedly fast tempo with punctuated accents played on the hanging gongs. It usually accompanies dance pieces that are not sacred in nature. The piece starts with a rising melody of four gong sounds, usually starting with the third gong in the set that transforms into a drone played on the fourth gong in the series. The piece is therefore a very percussive in character, featuring several drones or interlocking rhythmic patterns played for most part of the piece. As there is no set melody, and as rhythmic patterns may evolve according to individual players, Jose Maceda refers to the titik as a mode following a template or a rhythmic model of performance.

Bernard Ellorin has done extensive studies on Titik Tabawan in his master's thesis. He identifies variants played by three kulintangan masters based in Tawi-Tawi Province, Philippines. Furthermore, he confirms an alternate name for the piece or mode which comes by the name of Titik Tungkil. Based on the naming system, both pieces or modes are named after Tabawan Island and Tungkil Island, respectively. Tabawan is known for its complex rituals, refined dancing, healing and magic arts. In Tabawan Island itself, however, there is no piece called Titik Tabawan. Instead, a very rapid piece characterized by supplementary solembat or ostinatos played at the rims of two large agung called Titik Lenggang is performed to accompany both secular and sacred trance dances. Lenggang refers to the violent pitching or the unstable tipping of a boat in a rough seas. The frenetic rhythmic patterns of the piece, does evoke the roaring of waves and incessant murmuring of thunder in the midst of a stormy sea. Tungkil is a crescent-shaped island located northeast of Jolo Island, the seat of the defunct Sulu Sultanate. The sultans and datu of the Sulu Sultanate relied on the Sama Bangingi from the Island of Tungkil to man their slave-raiding expeditions. Slave-raiding may have spread this piece all over the Sulu-Sulawesi region and beyond.

Among the Sama Bangingi, there is likewise no piece called Titik Tungkil. Instead, its musical or percussive equivalent, is known among the Sama Bangingi as Titik Umaral. This piece is also found among 
the Sama Dilaut in the Zamboanga Peninsula, most probably a cultural appropriation resulting from cultural encounter between the two groups. Interestingly among the Yakan, Titik Umaral is a piece reserved for the accompaniment of dances performed by the kadatuan or royalty. Apart from the presence of subtle syncopation, complex double and triple beating of gongs used to ornament the basic rhythmic patterns, the Yakan version is likewise structurally similar to the other Titik Umaral found elsewhere. Ironically, Umaral is the cognate of Omadal, which in turn is the place name of the island where the oldest Sama Kubang graveyard are located, and where purportedly the earliest settlement of the Sama Kubang was established. Omadal may therefore be important as a possible place of origin for the Sama Sitangkai, Sama Kubang, Sama Bangingi, and Yakan. Further examination of oral narratives and lineages, as well as DNA analysis, may support or refute this hypothesis.

\section{Igal Tarirai: The Percussive Dance of the Island World of Sitangkai}

Igal Tarirai is a percussive dance that features the use of bamboo clappers called bolah-bolah. Apart from producing percussive sounds, the dancer engages in a playful interaction with the musicians through kinetic flourishes and held poses that correspond to specific musical ornamentation. Martenot and Maceda (1980) notes this one-to-one correspondence between music and movement in their description of a syncopated rhythm that "is accompanied by a quick, erotically suggestive jerking of the shoulders and torso." Studying the piece through participant observation and through in depth interviews of key informants, Ellorin (2008) is able to reconstruct the structure of the piece with the aid of emic musical concepts such as; the palinduan (the gong that usually starts and ends the piece), the taroroh (double beating executed on a gong and the tambul drum done at the end or $7^{\text {th }}$ count of each melodic phrase, in the first two repeated phrases; and the $3^{\text {rd }}$ and $7^{\text {th }}$ beats at the third phrase), and the pinaglabbuk (a slight pause immediate after the taroroh). This researcher (2017) examination of music-movement relationship reveals that the musical concepts correspond to indigenous movement ornamentation. The taroroh signals the dancer to execute any or a combination of the following: a jerking movement of her shoulders called kidjut-kidjut, a double-beating using her clappers, a sudden raising of a foot called sintak, a tip-toe called engkeh, and, a tendek-tendek or double stamping of the feet. The pinaglabbuk demands the suspension or holding of a pose. Movement structure therefore follows the musical structure.

Field research conducted in 2004 reveals three variant of the dance. In Sitangkai Island, the taroroh is usually ornamented with either a sintak (quick raising) or enke (tip-toe). The suspended movement corresponding to the pinaglabbuk pause is therefore the raised foot or the posture of the dancer in tip-toe. In Sibutu Island, particularly in the Village of Tongehat, the taroroh is ornamented with a double stamping of the feet ending en plier. The pinaglabbuk pause is therefore ornamented by the plier or bending of the legs held in a low pose. A third variant is produced by a married couple; Sumarin, the man, comes from Sibutu, while Bilbirasa, the woman, hails from Sitangkai. Bilbirasa executes the raised foot, while Sumarin performs the double stamping. This gendered variation is interesting for its contrast, the man being sharp and abrupt; and the woman being soft and gentle. Further research reveals that the sintak and enke movements are associated with Ennura Deminggu, an old dance master based in Sitangkai. Her style was further reworked by her pupil, Handa Saudagal, who incorporated extended legwork in her sintak.

In 2010, the researcher was fortunate enough to meet, Intan Sulga, a very talented dance master of Igal Tarirai from Bangau-Bangau, Semporna, Sabah State, Malaysia. Intan devised variants of rhythmic patterns played on the bolah-bolah. She also executed a very dainty version of the dance featuring what appears to be a swaying ambulation as she moved from one point of the performance space to another. Intan was later named Tokoh Hidup (Master of Living Tradition) by the Malaysian State in 2011. Observing examples of Igal Tarirai performances in Semporna, that of Intan included, reveals that the local version of this dance hews closely to the Sitangkai model that features the sintak or the raised foot. Follow up interviews validate the fact that Intan considers her lineage to originate from Sitangkai, and that her very own version of Igal Tarirai, sustains this form in her performance practice. As of the present, it appears that the Sibutu model which features double stamping of the feet, has not gained popularity in the region. Whether this is a temporary condition or one that is more or less sustained will be determined by performance practices in the future by the next generation of traditional dancers. Be it sintak or tendek-tendek, the origins and trajectories of shared culture can now very well be determined through ethnochoreomusicological methods that rely on emic concepts of sound and movement observable in the intangible cultural property of performance across cultural spheres or domains.

\section{Conclusion}


The examination of specific music pieces and dance forms or styles can help scholars understand how the seemingly disparate and widely-spread Sama-Bajau communities in Nusantara are related to each other. Three cases have been represented revolving around ritual, music, and dance. Although known by different names across communities, this music piece, which is used for accompanying secular forms belonging to the Sama-Bajau igal or pansak (aka pamansak) dance traditions, retains its distinct qualities of rhythmic patterns and remains discernible as a musical model to both practitioners and scholars alike.

\section{References}

Bottignolo, Bruno. Celebrations Under the Sun: An Overview of Religious Phenomena Among the Badjaos. Quezon City: Ateneo de Manila University Press, 1995.

Ellorin, Bernard. Variants of Kulintangan Performance as a Major Influence of Musical Identity Among the Sama in Tawi-Tawi, Philippines (Master of Arts in Music Thesis, University of Hawaii' in Manoa. Ann Arbor: ProQuest/UMI. (Publication No. AAT 1463075), 2008.

Martenot, Alain \& Jose Maceda. Sama de Sitangkai: Archipel de Sulu (Polyvinyl recording with Liner notes). Paris: Office de la Recherche Scientifique et Technique Outre-Mer Societe d' Etudes Linguistiques et anthropologiques de France, 1980.

Md. Nor, Anis \& Hussin, H. Gendering the Dance, Gazing Music: Dance Movements, Healing Rituals and Music Making, paper read at the International Council for Traditional Music World Conference, held in Newfoundland, Canada, July 13-19, 2011.

Nimmo, H. Arlo. Magosaha: An Ethnography of the Tawi-Tawi Sama Dilaut. Quezon City: Ateneo de Manila University Press, 2003).

Santamaria, MCM. A Percussive Dance: Exploring the Relationship of Sounding and Moving in the Sama-Bajau Igal Tariray. Paper presented at the 44th International Council of Traditional Music World Conference, held at the Irish World Academy, University of Limerick, Limerick, Ireland, July $13^{\text {th }}-19^{\text {th }}, 2017$. 